\title{
Arterial spin labeling CMR quantifies increased perfusion in hearts of mice treated with cardioprotective, AAV9-mediated EcSOD gene therapy prior to myocardial infarction Brent A French*, Konkal-Matt R Prasad, Moriel H Vandsburger, Ronald J Beyers, Yaqin Xu, Robert L Janiczek, Craig H Meyer and Frederick H Epstein
}

Address: University of Virginia, Charlottesville, VA, USA

* Corresponding author

from 13th Annual SCMR Scientific Sessions

Phoenix, AZ, USA. 2I-24 January 2010

Published: 21 January 2010

Journal of Cardiovascular Magnetic Resonance 2010, I2(Suppl I):P2I2 doi:I0.I 186/I532-429X-I2-SI-P2 I2

This abstract is available from: http://jcmr-online.com/content//2/SI/P2 I2

(c) 2010 French et al; licensee BioMed Central Ltd.

\begin{abstract}
Introduction
Experimental myocardial infarction (MI), direct gene transfer with adeno-associated viral (AAV) vectors and CMR in mice are powerful tools for studying the roles of individual genes in MI and post-MI left ventricular (LV) remodeling. Arterial spin labeling (ASL) enables the quantification of myocardial perfusion (MP) by CMR, but is sensitive to variable heart rates and irregular respiration, prohibiting accurate measurement early after MI. We developed a cardio-respiratory gated (CRG) ASL method that is insensitive to these factors to measure MP in mice.
\end{abstract}

\section{Purpose}

The objective of this study was to test the hypotheses that AAV9-mediated overexpression of extracellular superoxide dismutase (EcSOD) from the cardiac Troponin- $T$ (cTnT) promoter would increase capillary density and protect the heart against myocardial infarction (MI). Furthermore, we tested the hypothesis that an improved method of ASL could quantitate the elevation in MP resulting from increased capillary density.

\section{Methods}

CRG-ASL was developed on a $7 \mathrm{~T}$ MR system and employed to measure MP both before and 4 wks after gene therapy. AAV vectors were cross-packaged into AAV9 capsids expressing EcSOD or eGFP from the cTnT pro- moter (AcTnTEcSOD or AcTnTeGFP), and were injected IV into $4-5$ week-old $\mathrm{C} 57 \mathrm{Bl} / 6$ mice $\left(3 \times 10^{11} \mathrm{vp} /\right.$ mouse). Four weeks after injection, MI was induced by a $30 \mathrm{~min}$ coronary occlusion. Infarct size and area at risk (A@R) were measured $24 \mathrm{~h}$ later by TTC and Phthalo blue staining, respectively. Capillary density was measured 4 wks post injection in remote myocardium immunostained for CD31.

\section{Results}

MP as measured by CRG-ASL increased by $30 \%$ from 4.3 +0.5 before to $5.6+0.3 \mathrm{ml} / \mathrm{g}$-min at 4 wks post AcTnTEcSOD injection $(\mathrm{P}<0.05)$, then dropped to $2.4+0.6 \mathrm{ml} / \mathrm{g}$ min in the infarct zone $24 \mathrm{~h}$ post-MI. A single IV injection of AcTnTEcSOD provided uniform EcSOD overexpression throughout the myocardium (Panel A). Infarct size (as \% A@R, Panel B) was reduced by $45 \%$ in EcSOD mice (33.9 +6.3 , mean + SEM, $\mathrm{n}=4$ ) compared to eGFP mice (61.3 $+3.8, \mathrm{n}=4, \mathrm{P}<0.05)$. Capillary density was $23.6 \%$ higher in EcSOD mice $\left(5446+368 / \mathrm{mm}^{2}\right)$ compared to eGFP mice $\left(4405+271 / \mathrm{mm}^{2}, \mathrm{P}<0.05\right)$, Figure 1 .

\section{Conclusion}

CRG-ASL quantifies the increase in MP resulting from cardioprotective gene therapy with EcSOD. Transcriptional targeting with the cTnT promoter in combination with the high-efficiency AAV9 capsid provides cardioprotective 


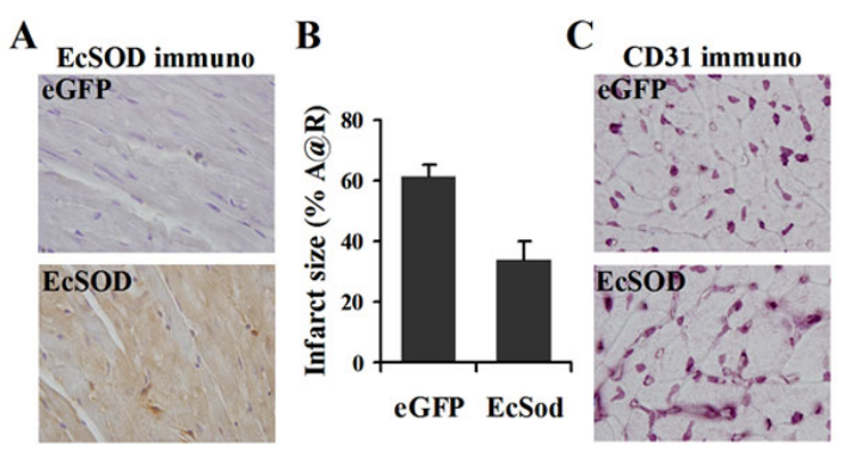

Figure I

gene therapy from a single IV injection. AAV9-mediated overexpression of EcSOD from the cTnT promoter significantly increases capillary density, improves myocardial perfusion and reduces infarct size in the murine heart.
Publish with Biomed Central and every scientist can read your work free of charge

"BioMed Central will be the most significant development for disseminating the results of biomedical research in our lifetime. "

Sir Paul Nurse, Cancer Research UK

Your research papers will be:

- available free of charge to the entire biomedical community

- peer reviewed and published immediately upon acceptance

- cited in PubMed and archived on PubMed Central

- yours - you keep the copyright

Submit your manuscript here:

http://www.biomedcentral.com/info/publishing_adv.asp 